Research article

urn:1sid:zoobank.org:pub:6328E049-24F3-42BE-A405-A79BF2F16EA8

\title{
Description of three new species of Caledomina (Insecta, Trichoptera, Ecnomidae) from New Caledonia
}

\author{
Kjell Arne JOHANSON \\ Zoology Department, Swedish Museum of Natural History, Box 50007, 10405 Stockholm, Sweden. \\ Email: kjell.arne.johanson@nrm.se \\ urn:1sid:zoobank.org:author:F2A38CF6-59EB-4F88-BFEB-761DBEA7B01A
}

\begin{abstract}
Three new species of Caledomina Johanson, 2011 are described and illustrated for the first time: C. paniensis sp. nov., C. dorsospina sp. nov. and C. kohensis sp. nov. A key to the males of the four known species in the genus is given, as well as a map indicating their geographical distribution. When examining a phylogenetic hypothesis comprising the four species, we see an increased complexity in younger species compared to older species.
\end{abstract}

Keywords. Caddisflies, endemic, Annulipalpia, New Caledonia, Oceania.

Johanson K.A. 2017. Description of three new species of Caledomina (Insecta, Trichoptera, Ecnomidae) from New Caledonia. European Journal of Taxonomy 352: 1-12. https://doi.org/10.5852/ejt.2017.352

\section{Introduction}

In total, about 470 extant species have been described in the family Ecnomidae, now divided into 11 extant genera and one fossil genus (Morse 2016). Seven of the genera (i.e., Absensomina Cartwright, 2010, Agmina Ward \& Schefter, 2000, Daternomina Neboiss, 2002, Ecnomina Kimmins, 1953, Neboissomina Cartwright, 2011, Wellsomina Cartwright, 2010 and Caledomina Johanson, 2011) are endemic to the Australasian plus Oceania biomes, representing $18.5 \%$ of the species diversity of the family. Of these, two genera (Agmina and Caledomina) are endemic to New Caledonia (Espeland \& Johanson 2010, Johanson \& Espeland 2010, Johanson 2011). In addition, 64 species in the genus Ecnomus McLachlan, 1864 are known from the Australasian biome, mainly described from Australia and Papua New Guinea. The classification of Ecnomidae of the Australasian biome was never fully understood and Espeland \& Johanson (2010) noted that the genus Ecnomina represented a polyphyletic group, partly resolved taxonomically by Cartwright $(2010,2011)$, who established three new genera for exclusively Australian species. Despite the improved classification of the Australian taxa, the genus Ecnomina still appears to be polyphyletic. The genus Caledomina was described to include a monophyletic group of four New Caledonian species, of which one, C. noumea Johanson, 2011, was described together with the genus. Below, the three other species are described in order to expand the knowledge of the morphological diversity within the group and the diversity of New Caledonian Trichoptera. 


\section{Material and methods}

The specimens in this study were collected in $80 \%$ ethanol using Malaise traps in November 2001 and November-December 2003. In the laboratory, the abdomens of the specimens were macerated by ProteinaseK for DNA sampling and mounted according to the method described by Johanson \& Ward (2009). Illustrations were produced using a drawing tube mounted on a Leitz Ortholux II light microscope. After illustrating, each abdomen was transferred to ethanol together with the rest of the animal. The nomenclature applied to morphological features follows that of Ward \& Schefter (2000). All material is deposited at the Muséum national d'Histoire naturelle, Paris, France (MNHN). DNA vouchers are deposited in Naturhistoriska riksmuseet, Stockholm (NHRS).

\section{Results}

Class Hexapoda Blainville, 1816

Order Trichoptera Kirby, 1813

Superfamily Hydropsychoidea Curtis, 1835

Family Ecnomidae Ulmer, 1903

Genus Caledomina Johanson, 2011

Caledomina paniensis sp. nov. urn:1sid:zoobank.org:act:6713A2D6-B4FF-4329-BEA9-952BB910F8D8

Figs $1-5,16,19$

FI4 Caledomina sp. 2 - Espeland \& Johanson 2010: 2116.

\section{Diagnosis}

Caledomina paniensis is distinguished from other species in the genus by the presence of a pair of sternal processes of sternite IX reaching about as long posteriorly as the inferior appendages.

\section{Etymology}

The specific epithet is derived from the type locality, Mount Panié.

\section{Type material}

\section{Holotype}

NEW CALEDONIA: ${ }^{\wedge}$, Province Nord, Mt Panié, river below waterfall, 20³5.864' S, $164^{\circ} 49.780^{\prime} \mathrm{E}$, 350 m, loc \#16-2001, Malaise trap, 22-28 Nov. 2001, Johanson, Pape and Viklund leg. (MNHN, DNA voucher: NHRS-FI4).

\section{Description}

WINGs. Fore wing length $2.2 \mathrm{~mm}$, hind wing length $1.6 \mathrm{~mm}$.

GenITALiA. Total length about $0.5 \mathrm{~mm}$. Segment IX divided into pair of strong, anteriorly pointed ridges in lateral view (Fig. 1); sternite IX originating from anterior ridge at mid-height; broadening posterad into pair of nearly parallel-sided plates with postero-dorsal sternal process (Fig. 1); smooth, except few ventral setae. Sternal processes short, slender, slightly curving dorsally, each with large apical and subapical spine nearly as long as sternal process (Figs 1,3); orienting posterad along their length in ventral view (Fig. 3); almost reaching point of bifurcation of superior appendages (Fig. 1). Tergite IX Y-shaped in lateral view (Fig. 1), anterodorsal corners strongly curving anterad before bending posterad at apex; with long setae on lateral faces; in dorsal view (Fig. 2) with anterior-most part fused mesally; posterior part divided into tapering branches. Tergite $\mathrm{X}$ membranous, present above posterior apex of 
tergite IX in lateral view (Fig. 1); in dorsal view divided into two lobes associated with branches of tergite IX; with minute setae along mesal margins (Fig. 2). Superior appendages large; each divided into posterior dorsal and ventral lobes (Fig. 1), with setae basally of bifurcation (Figs 1-2). Dorsal lobes smooth, except with long row of hook-like spines oriented ventro-mesad (Figs 1-2). Ventral lobes nearly straight along their length; ventral margin with minute spines; posterior apex narrowly rounded, covered with small setae; slightly exceeding dorsal lobe in length (Fig. 1). Inferior appendages completely fused into small, mesal process, connected to central part of sternite IX by vaguely defined sclerotized ridges; dorsal margin slightly sigmoid; ventral margin convex except curving at apex; apex long, narrow in lateral view (Fig. 1); in ventral view (Fig. 3) with broad basis; narrowing slightly at one quarter its length, apex smooth, bifurcated. Phallic apparatus without processes (Figs 4-5); tube-shaped; dorsal margin weakly narrowing at anterior one-third; posterior apex membranous.

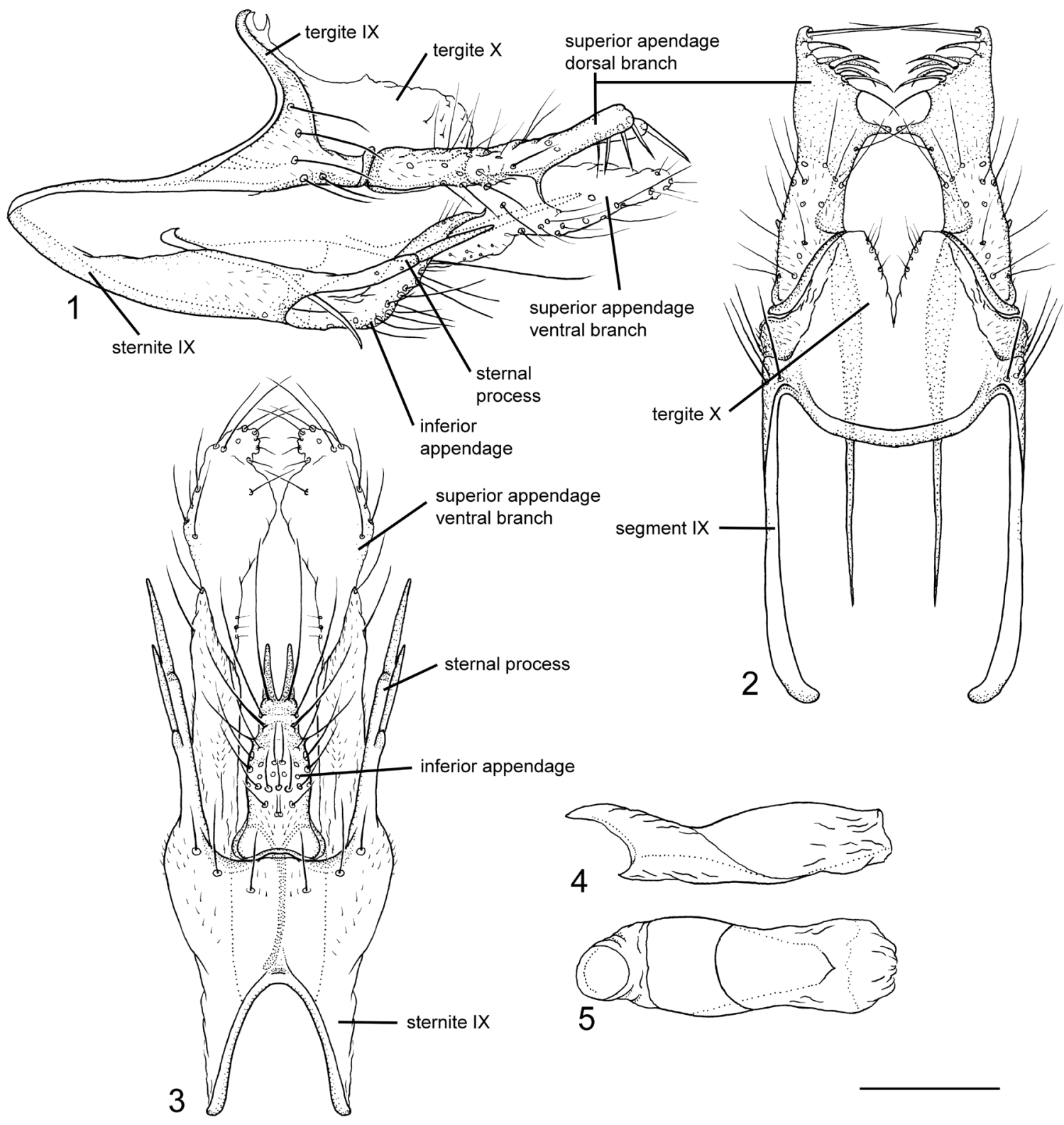

Figs 1-5. Caledomina paniensis sp. nov., holotype, adult $\widehat{\jmath}$. 1. Genitalia, lateral view. 2. Genitalia dorsal view. 3. Genitalia, ventral view. 4. Phallus, lateral view. 5. Phallus ventral view. Scale bar $=0.1 \mathrm{~mm}$. 


\section{Remarks}

This species was referred to as "FI4 Caledomina sp. 2" in Espeland \& Johanson (2010).

\section{Caledomina dorsospina sp. nov. urn:1sid:zoobank.org:act:147FDE5A-A7A6-4422-B30F-363F5BFAFBE5}

Figs 6-10, 16-17, 19

GS8 Caledomina sp. 3 - Espeland \& Johanson 2010: 2116.

\section{Diagnosis}

Caledomina dorsospina is distinguished from other species in the genus by the absence of a prominent sternal process of sternite IX, the dorsal branch of the superior appendages is oriented dorsally, and the ventral branch of the superior appendages is drop-shaped.

\section{Etymology}

Dorsospina, after the presence of a prominent dorsally oriented megaseta on each superior appendage.

\section{Type material}

\section{Holotype}

NEW CALEDONIA: ${ }^{\lambda}$, Province Sud, $1.0 \mathrm{~km}$ NW of Pont des Japonais, on road between Noumea and Yaté, $22^{\circ} 11.421^{\prime} \mathrm{S}, 166^{\circ} 42.840^{\prime} \mathrm{E}, 114 \mathrm{~m}$, loc \#038, Malaise trap, 22 Nov.-4 Dec. 2003, Johanson leg. (MNHN, DNA voucher: NHRS-GS8).

\section{Description}

Wings. Fore wing length $3.0 \mathrm{~mm}$, hind wing length $2.3 \mathrm{~mm}$.

GenitaLia. Total length about $0.6 \mathrm{~mm}$. Segment IX divided into pair of strong, antero-dorsally pointed ridges in lateral view (Fig. 6); sternite IX originating from anterior ridge below mid-height; anteriorly membranous, gradually more sclerotized posteriorly, posteriorly forming pair of nearly rectangular plates without postero-dorsal sternal process (Fig. 6); with ventral and lateral setae. Tergite IX almost U-shaped in lateral view (Fig. 6), anterodorsal corners strongly curving anterad and strongly pointed at apex; with long, strong setae in lateral row; in dorsal view (Fig. 7) with anterior-most part fused mesally; posterior part fused into superior appendages. Tergite $\mathrm{X}$ not visible (Fig. 6). Superior appendages very large; each divided into posterior dorsal and ventral lobes (Fig. 6), with setae basally of bifurcation (Figs 6-7). Dorsal lobes each with pair of very large megasetae, one at each apex and one sub-apically; mesal, finger-like branches present ventrally of megasetae, with sharp setae at each apex (Figs 6-7). Ventral lobes large, oval, oriented posterad, each with lateral face covered by large setae; mesal face with straight spines oriented mesally; ventral margin with minute setae; ventral branch strongly exceeding dorsal lobe posteriorly (Fig. 6). Inferior appendages completely fused into small, mesal process, connected to central part of sternite IX by well defined sclerotized ridges; dorsal margin smoothly sigmoid; ventral margin convex; apex long, narrow in lateral view (Fig. 6); in ventral view (Fig. 8) with broad basis; narrowing stepwise, apex smooth, bifurcated. Phallic apparatus without processes (Figs 9-10); tubeshaped; posterior two-thirds about twice as thick as anterior part in lateral view (Fig. 9); posterior apex membranous, with minute setae at dorsal membrane.

\section{Remarks}

This species was referred to as "GS8 Caledomina sp. 3" in Espeland \& Johanson (2010). 


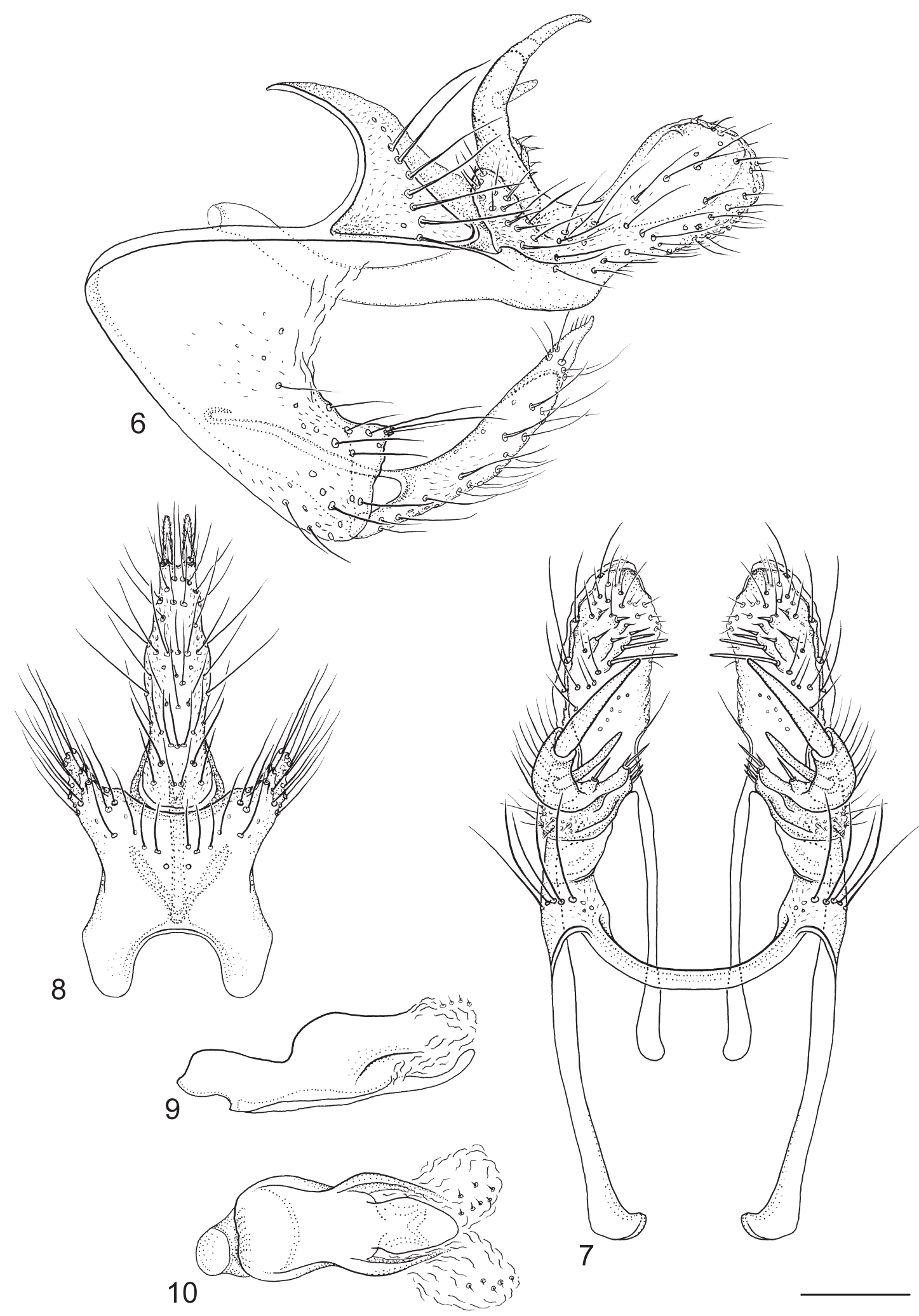

Figs 6-10. Caledomina dorsospina sp. nov., holotype, adult $\widehat{\jmath}$. 6. Genitalia, lateral view. 7. Genitalia dorsal view. 8. Genitalia, ventral view. 9. Phallus, lateral view. 10. Phallus ventral view. Scale bar $=$ $0.1 \mathrm{~mm}$. 


\section{Caledomina kohensis sp. nov. urn:1sid:zoobank.org:act:C659F3F5-8819-4F2F-887F-1EFA3423C49A}

Figs 11-16, 18-19

GV5 Caledomina sp. 1 - Espeland \& Johanson 2010: 2116.

\section{Diagnosis}

Caledomina kohensis is distinguished from all other species in the genus by the almost straight sternal process of sternite IX and the dorsal branch of the superior appendage with a row of spines on the mesal face.

\section{Etymology}

Kohensis, named after the village Koh near the type locality.

\section{Type material}

Holotype

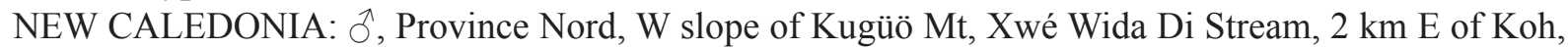
2135.474' S, 16550.776' E, 154 m, loc \#036, Malaise trap, 20 Nov.-12 Dec. 2003, Johanson leg. (MNHN, DNA voucher: NHRS-GV5).

\section{Description}

WiNGs. Wing length unknown as body is lost.

Genitalia. Total length about $0.5 \mathrm{~mm}$. Segment IX divided into pair of strong, anteriorly rounded ridges in lateral view (Fig. 11); sternite IX originating from anterior ridge below mid-height; broadening gradually posterad into sharply triangular plates with postero-dorsal sternal process (Figs 11, 13); smooth. Sternal processes slender, almost straight, with large apical spine nearly one-fourth as long as sternal process (Figs 11, 13); oriented posterad along their length in ventral view (Fig. 13); reaching slightly beyond point of bifurcation of superior appendages (Fig. 11). Tergite IX horseshoe-shaped in lateral view (Fig. 11), anterodorsal corners almost straight, oriented antero-dorsally; central part with long setae on lateral faces; in dorsal view (Fig. 12) with anterior-most part fused mesally, forming an undulating band; posterior part divided into broad branches (Fig. 11). Tergite X small, membranous, present above posterior apex of tergite IX in lateral view (Fig. 11); in dorsal view divided into two lobes associated with branches of tergite IX; with posterior and mesal setae (Fig. 12). Superior appendages large; each divided into posterior dorsal and ventral lobes (Fig. 11). Dorsal lobes oriented posteriorly, smooth except with series of long spines oriented mesally (Fig. 12). Ventral lobes originating gradually from anterior part of each tergite IX; nearly straight along their length; basal half of ventral face covered by minute spines (Fig. 13); each with posterior half slightly curving mesally and partly overlapping near apices; covered with setae; slightly exceeding dorsal lobe in length (Fig. 11). Inferior appendages completely fused into small, mesal process, connected to central part of sternite IX by sclerotized ridges (Fig. 11); dorsal margin slightly sigmoid; ventral margin convex; apex long, narrow in lateral view (Fig. 11); in ventral view (Fig. 13) with broad basis; narrowing strongly at one quarter its length, apex smooth, bifurcated. Phallic apparatus (Figs 14-15) with weakly developed ventrally pointed lobe (Fig. 14); irregularly tube-shaped; dorsal margin strongly narrowing at anterior one-third; posterior apex membranous.

\section{Remarks}

This species was referred to as "GV5 Caledomina sp. 1" in Espeland \& Johanson (2010). 


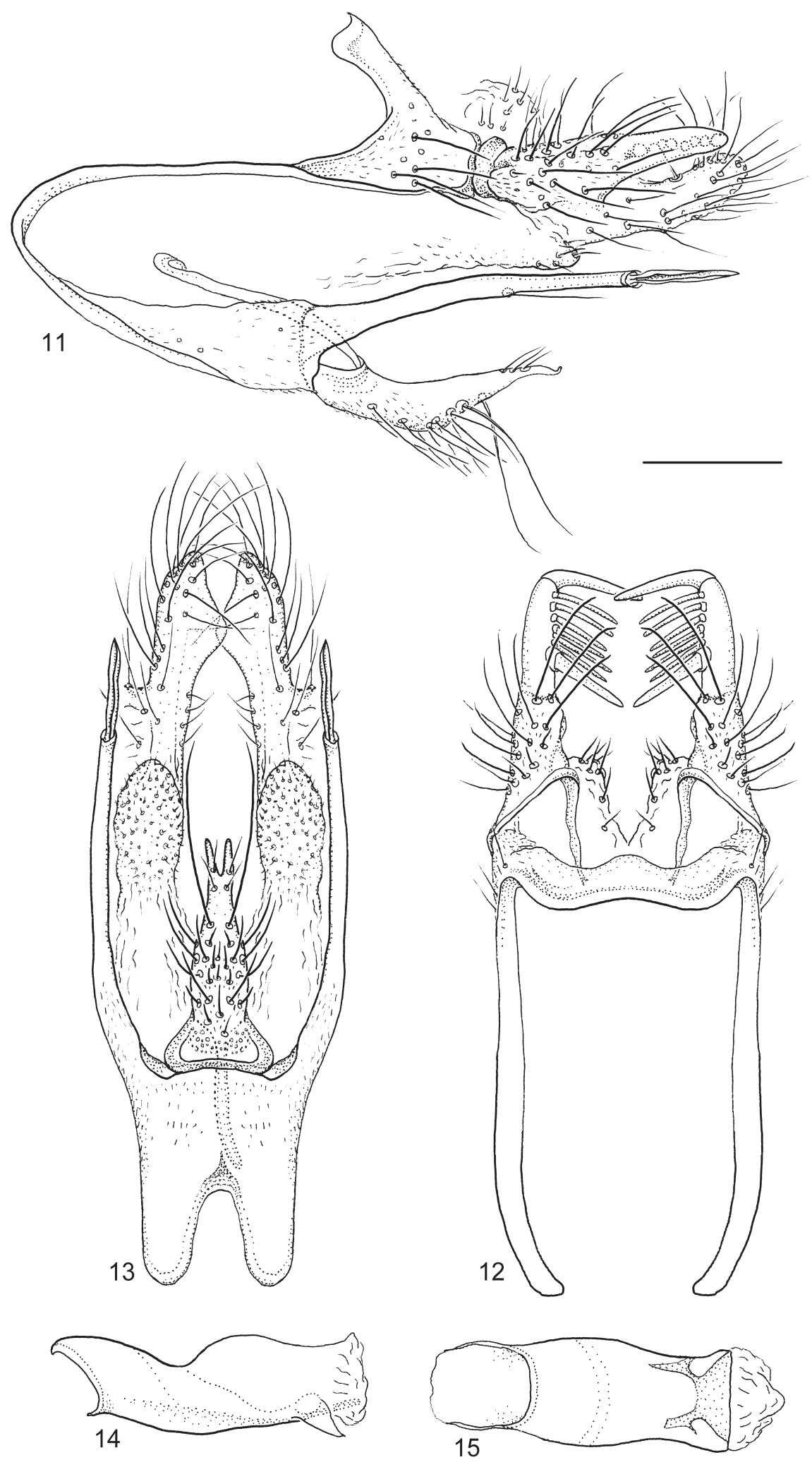

Figs 11-15. Caledomina kohensis sp. nov., holotype, adult $\widehat{~}$. 11. Genitalia, lateral view. 12. Genitalia dorsal view. 13. Genitalia, ventral view. 14. Phallus, lateral view. 15. Phallus ventral view. Scale bar $=$ $0.1 \mathrm{~mm}$. 


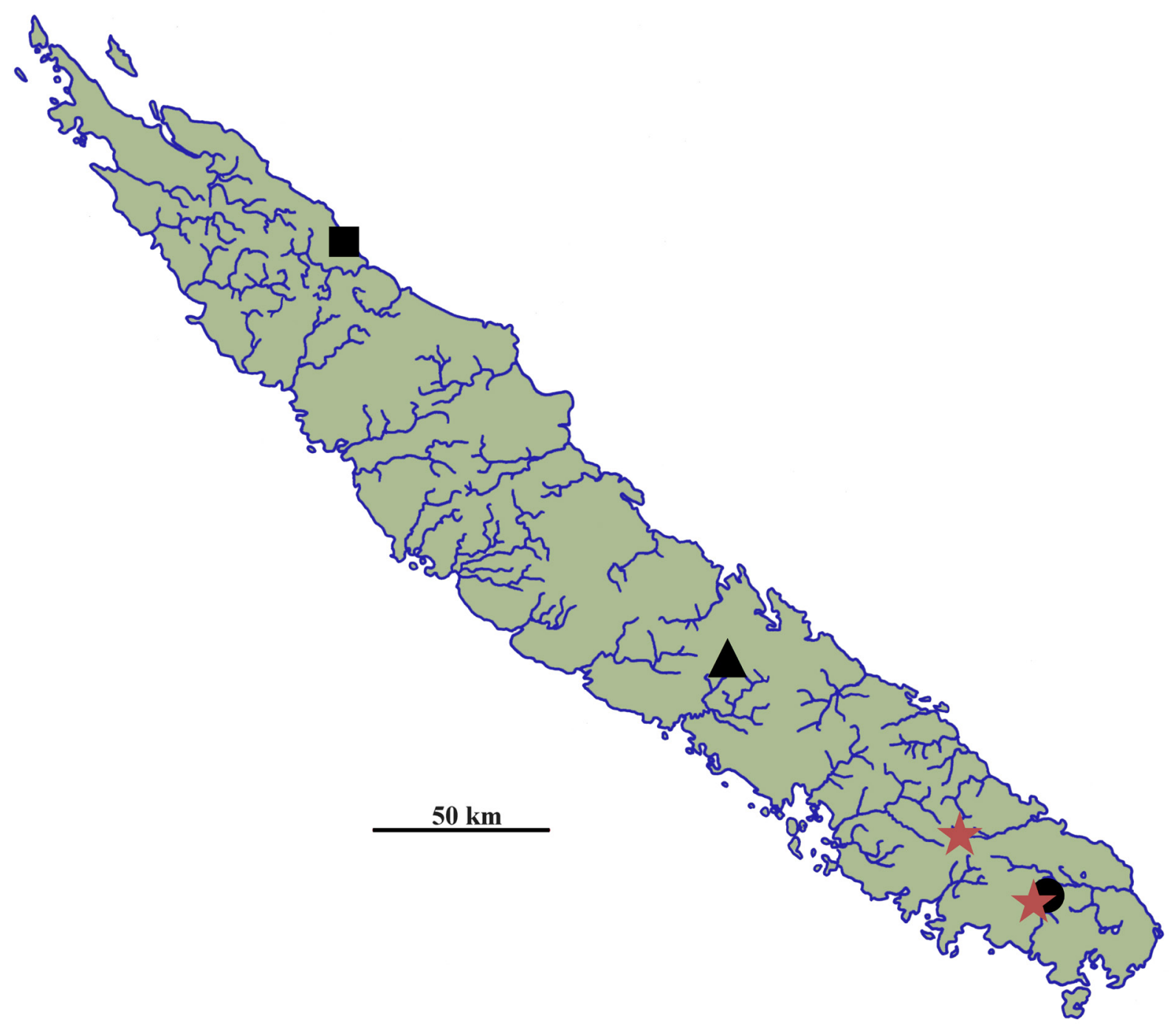

Fig. 16. Map of New Caledonia with collecting sites of Caledomina indicated. Caledomina paniensis sp. nov. (black square), C. dorsospina sp. nov. (black triangle), C. kohensis sp. nov. (black filled circle), C. noumea Johanson, 2011 (red stars). 


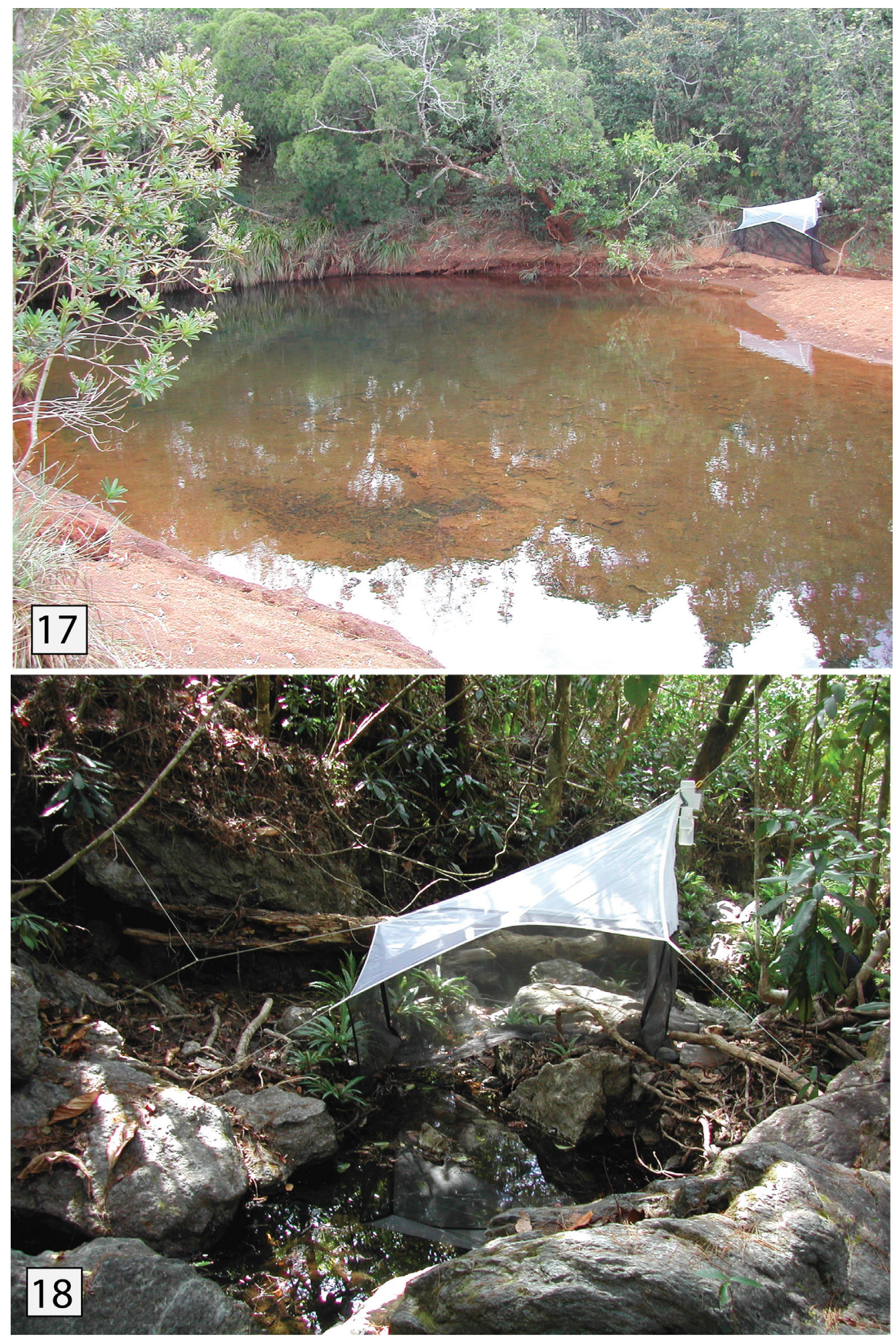

Figs 17-18. Type localities with Malaise traps. 17. Type locality of Caledomina dorsospina sp. nov. 18. Type locality of Caledomina kohensis sp. nov. 


\section{Key to males of Caledomina}

1. In genitalia, sternite IX without sternal process (Fig. 6); dorsal branch of superior appendage oriented dorsally (Fig. 6); ventral branch of superior appendage drop-shaped (Fig. 6)

C. dorsospina sp. nov.

- In genitalia, sternite IX with long sternal process (Figs 1, 11); dorsal branch of superior appendage oriented posteriorly (Figs 1, 11); ventral branch of superior appendage parallel-sided (Fig. 11) or tapering (Fig. 1)

2. In genitalia, tergite IX weakly produced dorsally (C. noumea in Fig. 19); dorsal branch of superior appendage apically curving ventrally and with ventrally oriented spines

C. noumea Johanson, 2011

- In genitalia, tergite IX strongly produced dorsally (Figs 1, 11); dorsal branch of superior appendage apically oriented posteriorly and with ventrally or mesally oriented spines

3. In genitalia, sternite IX with sternal process exceeding inferior appendage posteriorly (Fig. 11); dorsal branch of superior appendage with mesally oriented spines (Fig. 12)

C. kohensis sp. nov.

- In genitalia, sternite IX with sternal process shorter than inferior appendage (Fig. 1); dorsal branch of superior appendage with mesally and ventrally oriented spines (Figs 1-2)

C. paniensis sp. nov.
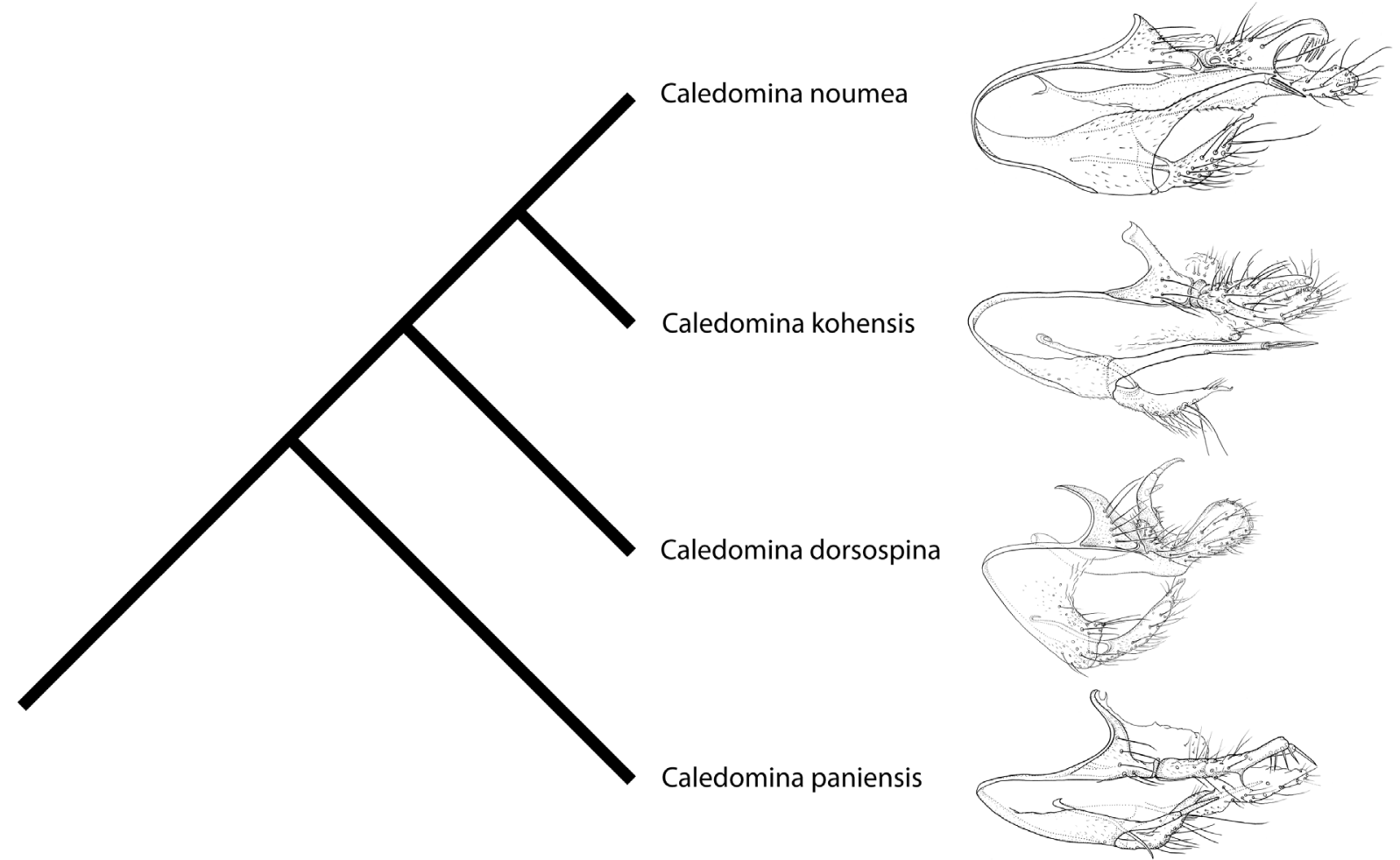

Fig. 19. Phylogenetic relationship among species of Caledomina, with morphology of male genitalia in lateral view to the right. 


\section{Discussion}

The phylogeny of Caledomina (Espeland \& Johanson 2010) demonstrates that the four species branch off sequentially from the first common ancestor to Caledomina and Ecnomina legula Neboiss, 1977. The complex genitalia were present in the oldest species (C. paniensis sp. nov.), involving a long sternal process of sternite IX including an apical spine; a pair of superior appendages bifurcated into about equally long dorsal and ventral branches, and strong spines present on each of the dorsal branches. An evolutionary trend apparently involves longer sternal processes, more complex spines on the dorsal branch of the superior appendages, and the sternite more strongly rounded anteriorly in the more derived species.

\section{Acknowledgements}

Many thanks go to the Direction des Ressources Naturelles (Noumea, New Caledonia), Environment Division, Department of Economic Development and Environment, Province Nord (Koné, New Caledonia) for providing collecting permits. Tin Sjöberg (NHRS) produced the line drawings.

\section{References}

Cartwright D.I. 2010. Descriptions of 2 new genera and 13 new species of caddisflies from Australia (Trichoptera: Ecnomidae). Zootaxa 2415: 1-21.

Cartwright D.I. 2011. Descriptions of Neboissomina, new genus and 6 new species of Ecnomidae from Australia (Trichoptera). Zootaxa 2736: 17-30.

Espeland M. \& Johanson K.A. 2010. The diversity and radiation of the largest monophyletic animal group on New Caledonia (Trichoptera: Ecnomidae: Agmina). Journal of Evolutionary Biology 23: 2112-2122. https://doi.org/10.1111/j.1420-9101.2010.02072.x

Johanson K.A. 2011. The ecnomid caddisflies: generic composition and a male-based generic key, with description of Caledomina noumea n. g. et n. sp. from New Caledonia (Trichoptera: Ecnomidae). Annales de la Société entomologique de France (N.S.) 47: 344-349. https://doi.org/10.1080/00379271 .2011 .10697726

Johanson K.A. \& Espeland M. 2010. Phylogeny of the Ecnomidae (Insecta: Trichoptera). Cladistics 26: 36-48. https://doi.org/10.1111/j.1096-0031.2009.00276.x

Johanson K.A. \& Ward J.B. 2009. Twenty-one new Polyplectropus species from New Caledonia (Trichoptera: Polycentropodidae). Annales de la Société entomologique de France (N.S.) 45: 11-47.

Morse J.C. (ed.) 2016. Trichoptera World Checklist. Available from http://entweb.clemson.edu/database/ trichopt/index.htm [accessed 28 March 2016].

Neboiss A. 2002. New genera and species, and new records, of Tasmanian Trichoptera (Insecta). Papers and Proceedings of the Royal Society of Tasmania 136: 43-82.

Ward J.B. \& Schefter P.W. 2000. A new genus and twenty new species of New Caledonian Ecnomidae (Trichoptera). Records of the Canterbury Museum 14: 55-87.

Manuscript received: 28 March 2016

Manuscript accepted: 9 January 2017

Published on: 22 September 2017

Topic editor: Gavin Broad

Desk editor: Chloe Chester 
Printed versions of all papers are also deposited in the libraries of the institutes that are members of the EJT consortium: Muséum national d'Histoire naturelle, Paris, France; Botanic Garden Meise, Belgium; Royal Museum for Central Africa, Tervuren, Belgium; Natural History Museum, London, United Kingdom; Royal Belgian Institute of Natural Sciences, Brussels, Belgium; Natural History Museum of Denmark, Copenhagen, Denmark; Naturalis Biodiversity Center, Leiden, the Netherlands; Museo Nacional de Ciencias Naturales-CSIC, Madrid, Spain; Real Jardín Botánico de Madrid CSIC, Spain. 